\title{
Intraspecific karyotypic variation in the silverside fish Chirostoma humboldtianum (Atheriniformes: Atherinopsidae)
}

\section{Variación cariotípica intraespecífica en el pez blanco Chirostoma humboldtianum (Atheriniformes: Atherinopsidae)}

\author{
Irma Urbina-Sánchez', Carmen Guadalupe Paniagua-Chávez², Reyna Fierro³ , Gerardo Figueroa-Lucero ${ }^{4}$ \\ and Irene de los Angeles Barriga-Sosa ${ }^{4}$
}

'Doctorado en Ciencias Biológicas y de la Salud. Universidad Autónoma Metropolitana Unidad Iztapalapa. Av. San Rafael Atlixco 186. Col. Vicentina, Iztapalapa, CDMX. 09340. México

²Departamento de Acuicultura, Centro de Investigación Científica y de Educación Superior de Ensenada, Baja California. Carretera Ensenada-Tijuana No. 3918, Zona Playitas, Ensenada, B.C. 22860. México ${ }^{3}$ Departamento de Ciencias de la Salud, Universidad Autónoma Metropolitana Unidad Iztapalapa, Av. San Rafael Atlixco 186. Col. Vicentina, Iztapalapa, CDMX. 09340. México 4Planta Experimental de Producción Acuícola, Departamento de Hidrobiología, Universidad Autónoma Metropolitana Unidad Iztapalapa, Av. San Rafael Atlixco 186.

Col. Vicentina, Iztapalapa, CDMX. 09340. México e-mail: ibs@xanum.uam.mx.

Urbina-Sánchez I., C. G. Paniagua-Chávez, R. Fierro, G. Figueroa-Lucero and I. A. Barriga-Sosa. 2016. Intraspecific karyotypic variation in the silverside fish Chirostoma humboldtianum (Atheriniformes: Atherinopsidae). Hidrobiológica 26 (1): 93-101.

\begin{abstract}
Within its genus, Chirostoma humboldtianum is one of the species with the widest distribution, inhabiting lake and pond environments along the Lerma-Santiago basin in the Mexican Plateau. Although the species is of great ichthyological, economic, and cultural relevance, factors related to human activity such as habitat loss, pollution, overfishing, and introduction of non-native fish have played important roles in the decline and disappearance of populations. With the aim of describing the karyotype of the species, 22 specimens of $C$. humboldtianum were collected and their chromosomes obtained from gills based on Denton (1973). Here we reveal intraspecific chromosome variation, characterized by five cytotypes found in four studied populations: 1) Las Tazas, Tiacaque dam $(2 \mathrm{n}=48, \mathrm{FN}=58)$ with chromosome formula $6 \mathrm{~m}$ $+4 s m+38 t ; 2)$; Villa Victoria dam $(2 n=48, F N=54) 2 m+2 s m+2 s t+42 t ; 3)$ Tepuxtepec dam, with two cytotypes ( $2 n$ $=48, F N=50) 8 m+2 s m+38 t$ and $(4 n=96, F N=116) 8 m+2 s t+38 t ; 4)$ and San Pedro Lagunillas lagoon $(2 n=48$, $\mathrm{FN}=58) 8 \mathrm{~m}+2 \mathrm{sm}+38 \mathrm{t}$. We observed chromosome variation in the morphology of pairs $1,2,4$, and 5 . Results allow us to suggest that pericentric inversions are the source of intraspecific chromosome variation. Comparative analyses support the hypothesis that the karyotype of the population from Villa Victoria dam represents the primitive form for the species.
\end{abstract}

Key words: Karyotype, Shortfin silverside, polyploidy, variation.

\section{RESUMEN}

Chirostoma humboldtianum es dentro del género, una de las especies con la más amplia distribución, habita ambientes lacustres y cuerpos de agua a lo largo del sistema Lerma-Santiago en la Mesa Central de México. Aunque la especie es de gran relevancia ictiológica, económica y cultural, factores relacionados con la actividad humana como la pérdida de hábitat, contaminación, sobrepesca y la introducción de peces no-nativos, han jugado un papel importante en la disminución y desaparición de poblaciones. Con el propósito de describir el cariotipo de la especie, se colectaron 22 individuos de $C$. humboldtianum y sus cromosomas se obtuvieron a partir de branquias de acuerdo a Denton (1973). En el presente trabajo se revela variación cromosómica intraespecífica caracterizada por cinco citotipos de cuatro poblaciones estudiadas: 1) Presa Las Tazas, Tiacaque $(2 \mathrm{n}=48, \mathrm{NF}=58)$ con las fórmulas cromosómicas $6 \mathrm{~m}+4 \mathrm{sm}+38 \mathrm{t}$; 2$)$ Presa Villa Victoria $(2 \mathrm{n}$ $=48, N F=54) 2 m+2 s m+2 s t+42 t ; 3)$ Presa Tepuxtepec, con dos citotipos $(2 n=48, N F=50) 8 m+2 s m+38 t$ y $(4 n$ $=96, N F=116), 8 m+2 s t+38 t ; 4)$ y Laguna San Pedro Lagunillas $(2 n=48, N F=58) 8 m+2 s m+38 t$. La variación cromosómica se detectó principalmente en la morfología de los pares 1, 2, 4 y 5. Los resultados encontrados permiten sugerir la presencia de inversiones pericéntricas como el principal mecanismo de variación cromosómica intraespecífica. El análisis comparativo de los datos apoya la hipótesis de que el cariotipo de la población Villa Victoria representa, la forma cromosómica primitiva de la especie.

Palabras clave: Citotipo, pez blanco, poliploidía, variación. 


\section{INTRODUCTION}

Among vertebrates, fish have the greatest number of species. Atheriniformes contains six, globally-recognized families, from which Atherinopsidae is exclusive to the New World (Nelson, 1994), and includes two genera restricted to inland waters of the Mexican plateau, Chirostoma and Poblana.

Chirostoma is the representative genus of the Atherinopsidae. It is endemic to Mexican ichthyofauna and includes the silversides "charales" and "peces blancos"; among the latter, C. humboldtianum (Valenciennes 1835) has the greatest but disjunct distribution, isolated in lakes and ponds from the Valley of Mexico to the Pacific Ocean following the Lerma-Chapala-Santiago basin system (Alvarez \& Navarro, 1957; Barbour, 1973 a, b). It also has high economic and cultural value (Jiménez \& Gracia, 1995; Soria-Barreto et al., 1998; Barriga-Sosa, 2001; Barriga-Sosa et al., 2002, 2004, 2005; Rojas \& Sasso, 2005).

Chirostoma humboldtianum faces several problems such as habitat reduction and modification (e.g., the groundwater extraction in the Basin of Mexico, Alvarez \& Navarro, 1957), pollution, introduction of exotic species (Barbour, 1973a; Berlanga-Robles et al., 2002), and translocations. These in turn played important roles in the decline and extirpation of local populations (Lyons et al., 1998; Soria-Barreto et al., 1998; Soto-Galera et al., 1998; Barriga-Sosa et al., 2002, 2004, 2005; Rojas \& Sasso, 2005; Mercado-Silva et al., 2006). In despite of all these threats to the species, it has not been designated as threatened in the Official Mexican Standard Norms (i.e., NOM-059-Semarnat-2010) or in the International Union for the Conservation of Nature (IUCN 2015).

Morphological and genetic studies on the "humboldtianum group" (a group mainly made up of "peces blancos", C. humboldtianum included) at the intra and interspecific level (Barriga-Sosa, 2001; BarrigaSosa et al., 2002), found the presence of significant morphological and genetic differences between populations of $C$. humboldtianum. These studies suggest that habitat diversity and geographic isolation might have played important roles on their heterogeneity. However, species distribution (populations within the same region) has been of limited interest. Only recently, García-Martínez et al. (2015), using mitochondrial
DNA sequences and including samples from six locations along the entire disjunct distribution of the species, have found evidence of a strong genetic structure of the species and have established the presence of at least six populations.

Where differences in the number and structure of chromosomes have been detected, cytogenetic analysis of fish have been used to characterize both populations (i.e., rainbow trout, Thorgaard, 1983; Ocalewicz \& Dobosz, 2009) and species (Ariids, Uribe-Alcocer, 1988; cichlids, Uribe-Alcocer et al., 1992, 1999; Hodaňová et al., 2014), contributing to the knowledge and understanding of the evolutionary history and relationships of organisms (White, 1973; Huxley, 1974; Mank \& Avise, 2006). For the members of Chirostoma, there is no information regarding intraspecific chromosome characterization, and of 18 recognized species, only five have been described as karyotypes (UribeAlcocer et al., 2002; Uribe-Alcocer \& Díaz-Jaimes, 2003). Thus, the aim of this study is to describe the karyotype of $C$. humboldtianum along its distribution in the Lerma-Chapala-Santiago basin in order to solve one important question: Does the species possess a conserved karyotype along its disjunct distribution?

\section{MATERIALS AND METHODS}

Fish sampling. We obtained twenty-two $C$. humboldtianum adults from stocks maintained in culture conditions in the Planta Experimental de Producción Acuícola at the Universidad Autónoma Metropolitana-Iztapalapa campus. The original stocks were collected from four natural locations (Table 1, Fig. 1) that correspond to what hereinafter we refer to as "populations" according to García-Martínez et al. (2015). Our populations originated on the high, middle, and low Lerma-ChapalaSantiago basin and were identified by their morphological characters according to Barbour (1973b).

Chromosome preparation. We obtained chromosome spreads from gill epithelium using a $1 \%$ sodium citrate hypotonic solution following Denton (1973). Slides with chromosomes were stained with $10 \%$ Giemsa Sörensen solution, pH 7 for 15 min. Mitotic chromosomes were screened in an Olympus CX31 microscope equipped with a digital Infi-

Table 1. Collecting sites for the analyzed Chirostoma humboldtianum.

\begin{tabular}{|c|c|c|c|c|c|}
\hline Collecting site & $\begin{array}{c}\text { Geographic } \\
\text { Coordinates (DMS) }\end{array}$ & $\begin{array}{l}\text { MASL } \\
(\mathrm{m})\end{array}$ & $\begin{array}{c}n \\
\text { Sex }\end{array}$ & $\begin{array}{l}\mathrm{TL} \\
(\mathrm{cm})\end{array}$ & $\begin{array}{l}\text { TW } \\
(g)\end{array}$ \\
\hline $\begin{array}{l}\text { 1. Las Tazas Tiacaque dam Jocotitlán, State of Mexico (T) } \\
\text { (OBS at PExPA) }\end{array}$ & $\begin{array}{l}19^{\circ} 38^{\prime} 29^{\prime \prime} \mathrm{N} \\
99^{\circ} 42^{\prime} 27^{\prime \prime} \mathrm{W}\end{array}$ & 2540 & $\begin{array}{l}6 \text { 웅 } \\
6 \text { o }\end{array}$ & $10.5-19.2$ & $5-20$ \\
\hline $\begin{array}{l}\text { 2. Villa Victoria dam, State of Mexico } \\
\text { (VV) (OBS at PExPA) }\end{array}$ & $\begin{array}{c}19^{\circ} 26^{\prime} \mathrm{N} \\
100^{\circ} 00^{\prime} \mathrm{W}\end{array}$ & 2570 & 40 & $9-11.5$ & $5-10$ \\
\hline $\begin{array}{l}\text { 3. Tepuxtepec dam, Contepec, Michoacan } \\
\text { (Tx) (OBS at PExPA) }\end{array}$ & $\begin{array}{l}20^{\circ} 00^{\prime} 09^{\prime \prime} \mathrm{N} \\
100^{\circ} 12^{\prime} 45^{\prime \prime} \mathrm{W}\end{array}$ & 2361 & $\begin{array}{l}2 \text { Q } \\
2 \stackrel{-\pi}{O}\end{array}$ & $10-13$ & $10-12$ \\
\hline $\begin{array}{l}\text { 4. San Pedro Lagunillas lagoon, Nayarit } \\
\text { (SP) (OBS at PExPA) }\end{array}$ & $\begin{array}{l}21^{\circ} 11^{\prime} 39^{\prime \prime} \mathrm{N} \\
104^{\circ} 43^{\prime} 44^{\prime \prime} \mathrm{W}\end{array}$ & 1248 & $2 \delta$ & $8.3-9.5$ & 4-9 \\
\hline
\end{tabular}

OBS = Original brood stock collected in the referred site; PExPA = Planta Experimental de Producción Acuícola; MASL = Meters above sea level; $n=$ Number of organisms analyzed 


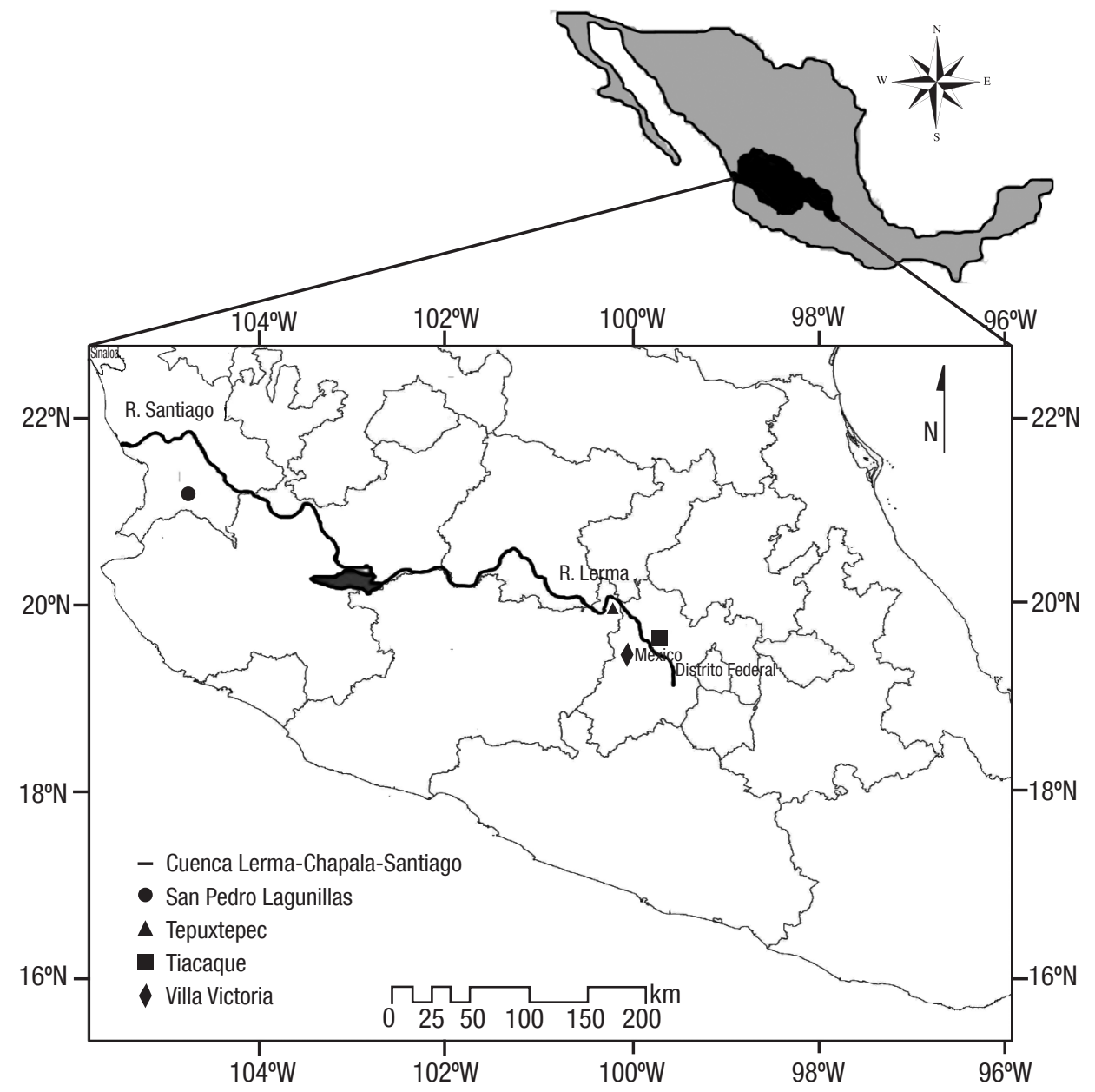

Figure 1. Map showing the collected localities (populations) from Chirostoma humboldtianum specimens.

nity 1 camera and 7.5X zoom. All images were processed using Adobe Photoshop CS5 Version 8.0.1. Ten mitoses of Las Tazas, Tiacaque dam population, four of Villa Victoria dam, six of Tepuxtepec dam and five of San Pedro Lagunillas, were measured to determine chromosome relative length. Centromeric index and arm ratios of chromosomes were used to classify them following Levan et al. (1964): a ratio from 1.0 to 1.7 for short to long arms ( $p$ and $q)$ corresponded to metacentric $(\mathrm{m})$; 1.71 to 3.0 to submetacentric (sm); between 3.1 and 7.0 to subtelocentric (st) and higher than 7.0 to telocentric (t) chromosomes. The fundamental number (FN) was determined as the total number of chromosome arms (Matthey, 1973). Ideograms were prepared according to the relative lengths of the short and long arms, as well as the centromere position (Denton, 1973) of each chromosome pair.

We analyzed differences between relative lengths of the most variable chromosome pairs in morphology of different cytotypes by a Wilcoxon-Mann-Whitney test (STATISTICA Version 10).

A UPGMA dendrogram was constructed in order to form groups based on cytotype similarities. A similarity matrix was built containing the following characters: 1) fundamental number; 2) numbers of metacentric, submetracentric, subtelocentric, and telocentric chromosomes; 3) morphology of pairs 1, 2, 4, and 5; and 4) the relative lengths of each chromosome pairs (1 to 24) and using the Bray-Curtis coefficient (MVSP Version 3.0, Kovach, 1998). We used the Similarity Percentage Analysis (SIMPER) (Clark, 1993) to determine the relative contribution of populations to dissimilarity between the resolved groups and average dissimilarity; the analysis was conducted in Past 3.03 (Hammer et al., 2001).

\section{RESULTS}

From 429 mitotic spreads analyzed from the four populations of $C$. humboldtianum, $70.39 \%$ revealed a diploid number of $2 n=48$ chromosomes. One specimen from Tepuxtepec dam exhibited a tetraploid karyotype $(4 n=96) 57.14 \%$ of the analyzed mitosis (12 out of 21 mitosis) for that specimen (Table 2).

Five cytotypes were resolved in the four populations analyzed: one cytotype for each one of the populations, Las Tazas, Tiacaque, and Villa 
Table 2. Number of individuals, preparations and mitosis analyzed per population of $C$. humboldtianum.

\begin{tabular}{lcccc}
\hline \multicolumn{1}{c}{ Population } & $\mathrm{n}$ & $\begin{array}{c}\text { Chromosome } \\
\text { slides }\end{array}$ & $\begin{array}{c}\text { Mitoses } \\
\text { spreads }\end{array}$ & $\begin{array}{c}\text { Measured } \\
\text { mitoses }\end{array}$ \\
\hline Las Tazas Tiacaque dam (T) & 12 & 12 & 295 & 10 \\
Villa Victoria dam (VV) & 4 & 4 & 42 & 4 \\
Tepuxtepec dam (Tx) & 4 & 4 & 51 & 6 \\
San Pedro Lagunillas lagoon (SP) & 2 & 2 & 41 & 5 \\
\hline
\end{tabular}

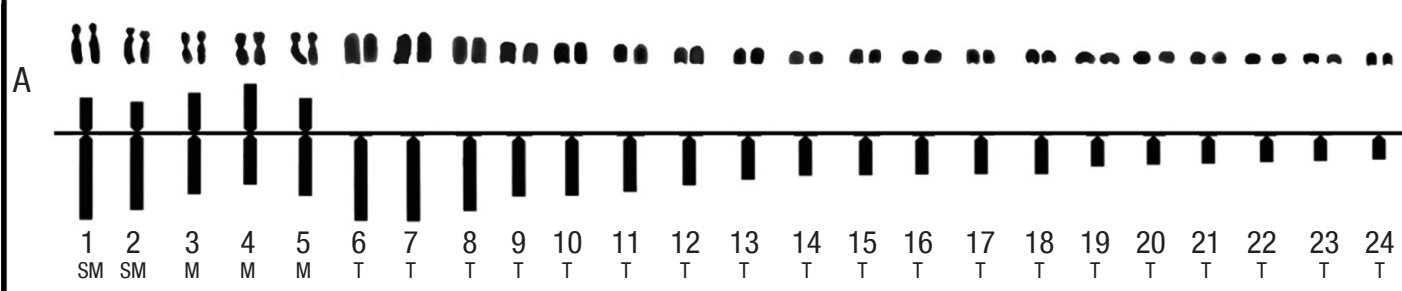

В \ل पा

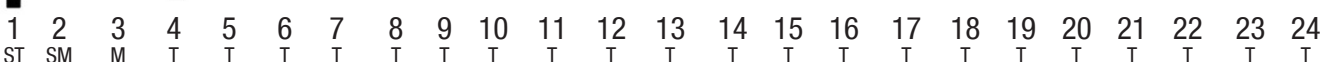

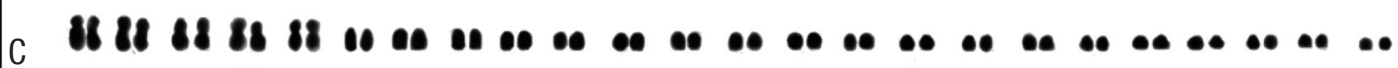

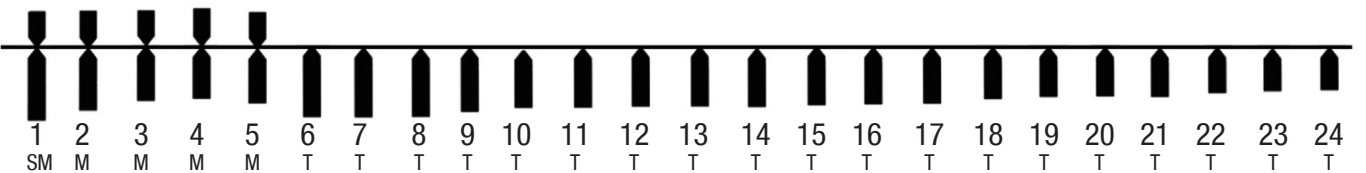

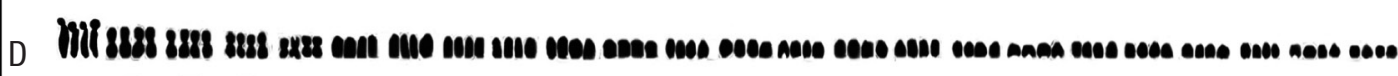
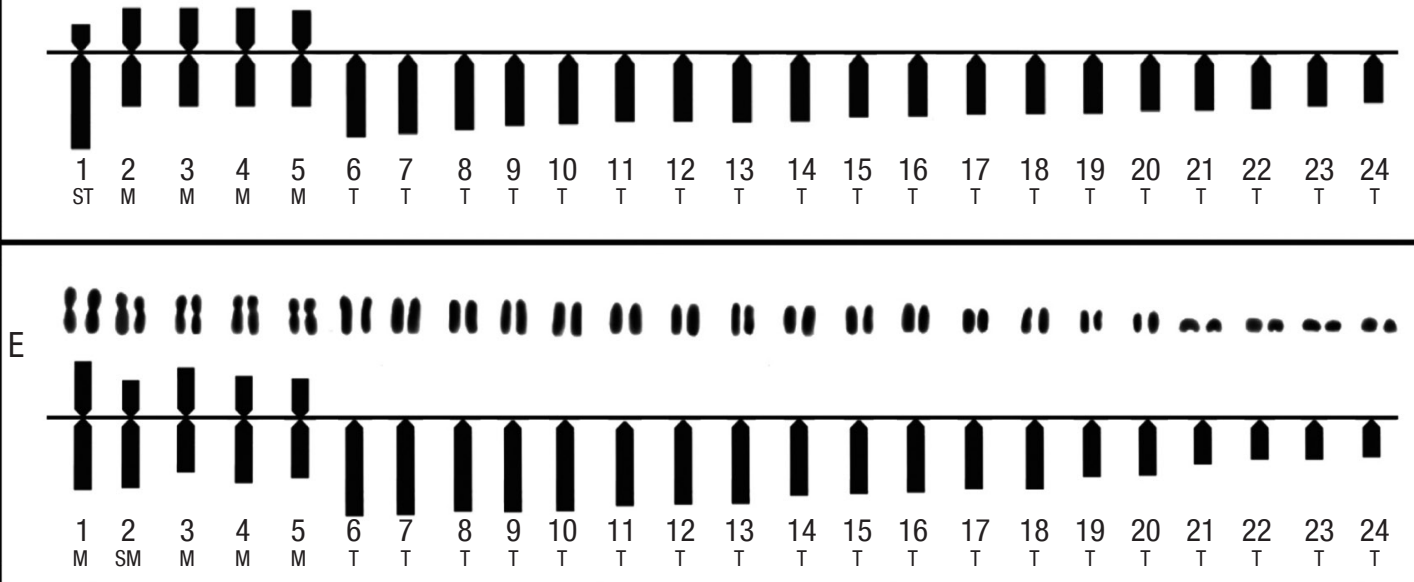

Figure 2. Karyotypes and idiograms of the five cytotypes resolved for Chirostoma humboldtianum. A. Female karyotype and idiogram from Las Tazas Tiacaque dam $(2 \mathrm{n}=48, \mathrm{FN}=58)$; B. Male karyotype and idiogram from Villa Victoria dam $(2 \mathrm{n}=48, \mathrm{FN}=54)$; C. Female karyotype and idiogram from Tepuxtepec dam $(\mathrm{Cl}, 2 \mathrm{n}=$ $48, \mathrm{FN}=58)$; D. Male karyotype and idiogram from Tepuxtepec dam (Cll, $4 \mathrm{n}=96, \mathrm{FN}=116)$; E. Male karyotype and idiogram from San Pedro Lagunillas lagoon $(2 \mathrm{n}$ $=48, \mathrm{FN}=58$. 
Table 3. Chromosomal characters of the five cytotypes described for $C$. humboldtianum.

\begin{tabular}{|c|c|c|c|c|c|c|c|c|c|c|}
\hline \multirow{2}{*}{ Cytotypes } & \multirow{2}{*}{ Sex } & \multirow{2}{*}{ DN } & \multirow{2}{*}{ FN } & \multirow{2}{*}{$\mathrm{CF}$} & \multicolumn{6}{|c|}{ Pair morphology } \\
\hline & & & & & 1 & 2 & 3 & 4 & 5 & $6-24$ \\
\hline $\mathrm{T}$ & 우 & $2 n=48$ & 58 & $6 \mathrm{M}+4 \mathrm{Sm}+38 \mathrm{~T}$ & $\mathrm{Sm}$ & $\mathrm{Sm}$ & $M$ & $M$ & $\mathrm{M}$ & $\mathrm{T}$ \\
\hline W & o & $2 n=48$ & 54 & $2 \mathrm{M}+2 \mathrm{Sm}+2 \mathrm{St}+42 \mathrm{~T}$ & St & $\mathrm{Sm}$ & M & $\mathrm{T}$ & $\mathrm{T}$ & $\mathrm{T}$ \\
\hline $\mathrm{Tx} \mathrm{Cl}$ & 우 & $2 n=48$ & 58 & $8 \mathrm{M}+2 \mathrm{Sm}+38 \mathrm{~T}$ & $\mathrm{Sm}$ & M & M & M & M & $\mathrm{T}$ \\
\hline Tx Cll & 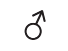 & $4 n=96$ & 116 & $8 \mathrm{M}+2 \mathrm{St}+38 \mathrm{~T}$ & St & M & M & $M$ & M & $\mathrm{T}$ \\
\hline SP & 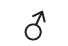 & $2 n=48$ & 58 & $8 \mathrm{M}+2 \mathrm{Sm}+38 \mathrm{~T}$ & $M$ & $\mathrm{Sm}$ & $M$ & $M$ & $M$ & $\mathrm{~T}$ \\
\hline
\end{tabular}

T = Las Tazas Tiacaque dam; VV = Villa Victoria dam; Tx Cl = Tepuxtepec dam, Cytotype I; Tx CII = Tepuxtepec dam, Cytotype II; SP = San Pedro Lagunillas lagoon; $\mathrm{DN}=$ Diploid number; FN = Fundamental number; $\mathrm{CF}=$ Chromosome formulae; $\mathrm{M}=$ Metacentric; $\mathrm{Sm}=$ submetacentric; $\mathrm{St}=$ subtelocentric; $\mathrm{T}=$ telocentric; ᄋ $=$ Female; $\hat{\delta}=$ male.

Victoria dams and San Pedro Lagunillas lagoon, and two cytotypes in Tepuxtepec dam (Tables 2, 3, and Fig. 2).

No pairs of heteromorphic chromosomes that could correspond to sex chromosomes were identified in any of the studied populations.
All chromosome pairs were ordered by size, from the largest to the smallest (Table 4 and Fig. 2).

Chromosome pairs 1, 2, 4, and 5 were the most variable in morphology. Pair 1 was submetacentric and subtelocentric for the cytoty-

Table 4. Relative chromosome length averages of the cytotypes of Chirostoma humboldtianum.

\begin{tabular}{|c|c|c|c|c|c|}
\hline $\begin{array}{c}\text { Chromosome } \\
\text { Pair }\end{array}$ & $\mathrm{T}$ & VV & $\mathrm{Tx} \mathrm{Cl}$ & Tx Cll & $\mathrm{SP}$ \\
\hline 1 & $8.24 \pm 2.673$ & $9.16 \pm 3.490$ & $7.10 \pm 1.145$ & $7.35 \pm 1.383$ & $6.82 \pm 1.938$ \\
\hline 2 & $7.20 \pm 1.628$ & $7.01 \pm 2.952$ & $6.62 \pm 1.083$ & $5.76 \pm 1.449$ & $5.53 \pm 2.249$ \\
\hline 3 & $6.79 \pm 4.071$ & $6.73 \pm 0.552$ & $6.15 \pm 0.849$ & $5.75 \pm 0.873$ & $5.50 \pm 1.007$ \\
\hline 4 & $6.62 \pm 2.071$ & $6.56 \pm 4.324$ & $6.15 \pm 1.501$ & $5.02 \pm 0.702$ & $5.42 \pm 0.469$ \\
\hline 5 & $6.27 \pm 1.071$ & $5.06 \pm 0.143$ & $6.13 \pm 0.532$ & $4.66 \pm 0.623$ & $5.21 \pm 1.671$ \\
\hline 6 & $6.02 \pm 2.584$ & $5.05 \pm 0.566$ & $4.51 \pm 0.695$ & $4.65 \pm 0.893$ & $5.10 \pm 0.679$ \\
\hline 7 & $5.99 \pm 1.206$ & $4.42 \pm 0.525$ & $4.49 \pm 0.569$ & $4.37 \pm 0.701$ & $5.10 \pm 0.211$ \\
\hline 8 & $5.24 \pm 1.490$ & $4.41 \pm 0.659$ & $4.45 \pm 0.657$ & $4.50 \pm 0.881$ & $4.83 \pm 0.720$ \\
\hline 9 & $4.26 \pm \pm 1.73$ & $4.29 \pm 1.759$ & $4.06 \pm 1.115$ & $4.22 \pm 0.508$ & $4.82 \pm 0.886$ \\
\hline 10 & $4.22 \pm 0.898$ & $3.81 \pm 2.569$ & $3.88 \pm 0.984$ & $4.13 \pm 0.443$ & $4.74 \pm 0.301$ \\
\hline 11 & $3.76 \pm 1.095$ & $3.77 \pm 1.385$ & $3.75 \pm 0.465$ & $4.01 \pm 0.719$ & $4.40 \pm 1.198$ \\
\hline 12 & $3.45 \pm 0.615$ & $3.65 \pm 1.446$ & $3.74 \pm 0.626$ & $4.01 \pm 0.409$ & $4.39 \pm 0.952$ \\
\hline 13 & $3.18 \pm 1.584$ & $3.37 \pm 2.174$ & $3.73 \pm 0.920$ & $3.98 \pm 0.858$ & $4.38 \pm 1.183$ \\
\hline 14 & $2.82 \pm 0.571$ & $3.34 \pm 0.627$ & $3.72 \pm 0.398$ & $3.84 \pm 0.600$ & $4.10 \pm 1.233$ \\
\hline 15 & $2.82 \pm 0.880$ & $3.33 \pm 1.072$ & $3.59 \pm 0.436$ & $3.73 \pm 0.789$ & $3.90 \pm 0.884$ \\
\hline 16 & $2.79 \pm 0.692$ & $3.29 \pm 1.421$ & $3.53 \pm 0.272$ & $3.72 \pm 0.826$ & $3.85 \pm 0.008$ \\
\hline 17 & $2.79 \pm 0.243$ & $3.29 \pm 0.329$ & $3.53 \pm 0.277$ & $3.53 \pm 0.312$ & $3.61 \pm 0.008$ \\
\hline 18 & $2.74 \pm 0.645$ & $3.28 \pm 0.795$ & $3.23 \pm 0.393$ & $3.52 \pm 0.847$ & $3.60 \pm 0.160$ \\
\hline 19 & $2.59 \pm 1.125$ & $3.04 \pm 1.065$ & $3.15 \pm 0.637$ & $3.43 \pm 0.911$ & $3.10 \pm 2.131$ \\
\hline 20 & $2.56 \pm 0.626$ & $2.96 \pm 0.627$ & $3.10 \pm 0.612$ & $3.39 \pm 1.021$ & $2.91 \pm 1.056$ \\
\hline 21 & $2.53 \pm 0.800$ & $2.94 \pm 0.444$ & $2.97 \pm 0.437$ & $3.38 \pm 0.686$ & $2.31 \pm 0.776$ \\
\hline 22 & $2.43 \pm 0.509$ & $2.54 \pm 1.620$ & $2.93 \pm 0.544$ & $3.16 \pm 0.868$ & $2.10 \pm 0.845$ \\
\hline 23 & $2.37 \pm 0.455$ & $2.43 \pm 0.803$ & $2.89 \pm 0.469$ & $3.01 \pm 0.541$ & $2.09 \pm 0.752$ \\
\hline 24 & $2.33 \pm 0.848$ & $2.26 \pm 0.131$ & $2.60 \pm 0.664$ & $2.90 \pm 0.540$ & $1.98 \pm 0.735$ \\
\hline
\end{tabular}

Las Tazas Tiacaque dam (T), Villa Victoria dam (VV), Tepuxtepec dam, Cytotype I (TxCI), Tepuxtepec dam, Cytotype II (TxCII), San Pedro Lagunillas lagoon (SP). 
pes from Tepuxtepec. Pair 2 was metacentric in both cytotypes from Tepuxtepec dam and submetacentric in the cytotypes from Las Tazas, Tiacaque, and Villa Victoria dams and San Pedro Lagunillas lagoon. Pairs 4 and 5 were metacentric in Las Tazas, Tiacaque, and Tepuxtepec dams and San Pedro Lagunillas lagoon, and acrocentric in Villa Victoria dam. However, their relative lengths did not show differences $(P=$ $0.591,0.9079,0.591$, and 0.6099 , for pairs $1,2,4, \& 5$, respectively).

The constructed dendrogram using 33 chromosome characters allowed the identification of three groups. Based on their similarity, Las Tazas, Tiacaque, and Villa Victoria dams made up group I. The cytotypes from Tepuxtepec dam and San Pedro Lagunillas lagoon were placed in group II (Fig. 3). Geographically, group I corresponds to individuals from the high Lerma-Chapala-Santiago basin, and group II to individuals from the middle and lower basin. The SIMPER analysis identified the population that contributed most strongly to the configuration of groups. Average dissimilarity for both groups was 35\%. The contribution of dissimilarity of the populations of $C$. humboldtianum from Villa Victoria dam (35.42\%) and San Pedro Lagunillas (35.46\%) are close to the overall average dissimilarity, thus, the these populations appear to contribute the most to the conformation of Groups I and II.

\section{DISCUSSION}

The four populations of $C$. humboldtianum analyzed in this study showed a diploid number $(2 n=48)$, which concurs with the most frequent diploid number found in Atheriniformes (Atherinopsidae, in Labidesthes, Membras and Menidia, Jeffrey \& Fitzsimons, 1987; Warkentine et al., 1987; Odontesthes, Sola et al., 1988; Basilichthys, Gajardo, 1992; and Atherinella, Da Silva Cortinhas et al., 2003; Sczepanski et al., 2007). It is also considered to be the ancestral number for several freshwater teleost fish (i.e., salmonids, Amaro et al., 1996; cichlids, Thompson, 1979; Arias-Rodríguez et al., 2006) and even marine fishes (Galetti et al., 2000). Overall, within the family, the diploid number $2 n=48$ is a conserved characteristic, except for $C$. patzcuaro $(2 n=44)$ (UribeAlcocer et al., 2002; Uribe-Alcocer \& Díaz-Jaimes, 2003).

On the other hand, the fundamental number (FN) in Chirostoma humboldtianum populations was variable ( $\mathrm{FN}=54,58$ and 116). Variation in FN can be explained either by the occurrence of chromosomal rearrangements consistent with pericentric inversions and/or heterochromatin additions (Jackson, 1971; Thitiot-Quiévreux, 1994; Appels et al., 1998; Sobti et al., 2002). These rearrangements can affect only the fundamental number, but not the diploid number (Appels et al., 1998; Sobti et al., 2002). These patterns are common in fish and play a significant role in fish chromosomal evolution (i.e., Cyprinidae, Uyeno \& Miller, 1973; Cichlidae, Thompson, 1979; Atherinopsidae, Jeffrey \& Fitzsimons, 1987; Uribe-Alcocer et al., 2002; Muñoz et al., 2006; Carangidae, Lobotidae and Sciaenidae, Tripathy \& Das, 1988; and Batrachoididae, Merlo et al., 2005). Particularly within Atheriniformes the FN is very variable, with chromosome arms recorded from 44 to 86 , and such variation has been related to pericentric inversion rearrangements (Jeffrey \& Fitzsimons, 1987; Warkentine et al., 1987; Sola et al., 1988; Gajardo, 1992; Uribe-Alcocer et al., 2002; Da Silva Cortinhas et al., 2003; Sczepanski et al., 2007).

Although morphological variation was detected in chromosomes pairs 1, 2, 4, and 5 of Chirostoma humboldtianum, non-significant differences were observed when their relative lengths were compared; hence we explain the changes in the morphology of these pairs by

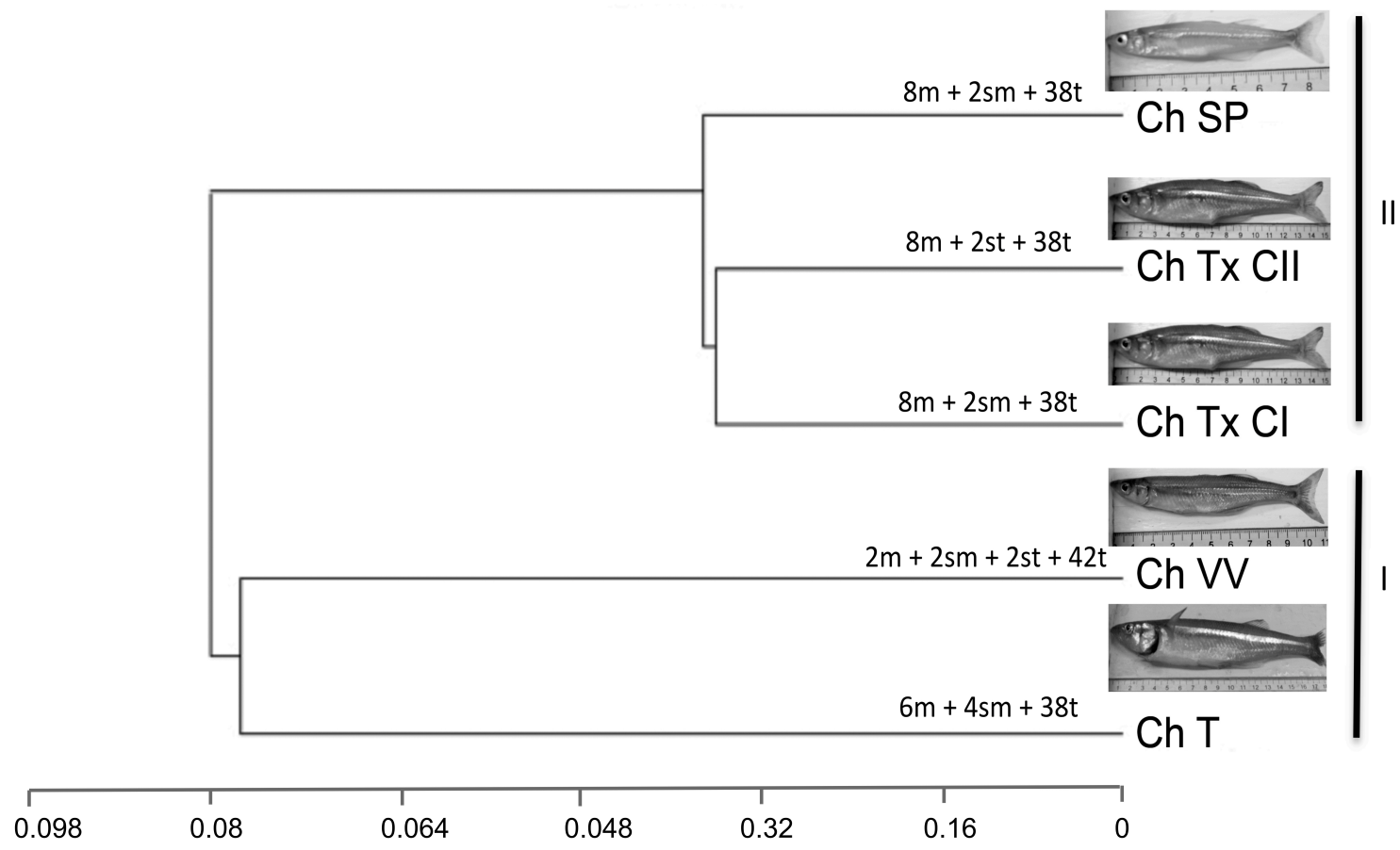

Figure 3. Dendogram based on chromosomal characters of the five cytotypes for $C$. humboldtianum (FN, morphology of the pairs 1, 2, 4 and 5; and relative length of all chromosome pairs) and using Bray-Curtis distances. The chromosome formulae resolved for each cytotype are shown. 
rearrangements of the pericentric-inversion type rather than by heterochromatin addition.

Considering that pericentric inversions are the most frequent rearrangements detected on the resolved karyotype variation of $C$. humboldtianum, then the hypothesis of a process of orthoselection, in which only one type of chromosome rearrangement occurs repeatedly within a species (White, 1973, 1978, \& 1978a), could be proposed as the predicted mutation model for the species. Although karyotype analysis with a larger sample size is suggested to estimate chromosome mutation rate (King, 1993), the presence of at least two different cytotypes in the population in the Tepuxtepec dam population allows us to support the proposed hypothesis.

The arrangement observed in the inferred dendrogram, conformed by two resolved groups, supported by the SIMPER average dissimilarity concurs with the preliminary layout of disjunct distribution of the species, where each population possesses a different cytotype, indicating geographic isolation and a process where intraspecific karyotype diversification might promote allopatric speciation (Key 1968, fide in King 1993). This proposal is supported by intraspecific variation previously reported for the species at the morphological, meristic, and allozyme level, which were also explained by the geographic isolation of the studied populations (Barriga-Sosa 2001; Barriga-Sosa et al., 2002), and more recently with sequences of the mitochondrial genome by GarcíaMartínez et al. (2015), where a high degree of genetic divergence between the studied populations was confirmed.

The results presented here allow us to suggest that the cytotype from the Villa Victoria dam could represent the most primitive karyotype described so far for Chirostoma humboldtianum and for the genus; this is so basically because it contains the largest number of single-armed chromosomes, it coincides with the diploid number of 48 , also considered the primitive teleost karyotype in about 200 fish species (Nayyar, 1966; Gyldenholm \& Scheel, 1971; Thompson, 1979; Rab et al., 1983; Feldberg \& Bertollo, 1985; Salas \& Boza, 1991; Martins et al., 1995; Uribe-Alcocer et al., 1992, 1999; Arias-Rodriguez et al., 2006), and is supported by the relative contribution of this population to the SIMPER average dissimilarity.

With respect to the polyploid organism that we found at the Tepuxtepec dam, we explain its presence by a possible autopolyploid mechanism, according to Leggatt \& Iwama (2003) and Vasil'ev (2009), where the entire chromosomal complement could be derived from only one parental species. In this species, the fertilization of the haploid egg occurs by haploid sperm with subsequent errors in meiotic reduction, due to abrupt changes in experimental conditions, such as temperature or exposure to high hydrostatic pressure (Arai, 2001), which in turn, leads to spontaneous autotetraploids, that are not morphologically different from their diploid counterparts. The tetraploid specimen described in the present study was a male and showed no apparent morphological differences to their diploid counterparts from the same population (Table 1). Spontaneous autopolyploids have been reported in a closely related silversides, Menidia sp, Odontesthes x Patagonina (Schultz, 1980; Strüssmann et al., 1993, 1997), and in other teleost fish, (i.e., cyprinids, Machordom \& Doadrio, 2001; Leggatt \& Iwama, 2003; Steven \& Smith, 2004; and acipenserids, Schreier et al., 2013); however, in order to test this hypothesis, further studies are required (i.e., crosses between populations and/or polyploid induction).
In summary, the most common diploid number in the genus Chirostoma is $2 n=48$. The intraspecific karyotype variation encountered in $C$. humboldtianum was caused by rearrangements of the pericentrictype inversions and could be associated to its disjunct distribution. The chromosome changes observed within the species could respond to a process of karyotype orthoselection. The tetraploid organism encountered in Tepuxtepec is likely to have resulted from an autopolyploid mechanism.

\section{ACKNOWLEDGEMENTS}

This research is part of the Ph.D. dissertation of the first author at the División de Ciencias Biológicas y de la Salud UAM-Iztapalapa. The first author had a CONACyT Ph.D. Scholarship 174845. This study was funded by SEP-CONACYT-2009-01-130220 and by a UAM.147.07.03/147.09.01 grant to IDLABS. The Mexican government kindly issued permit number DGOPA.07343.310810.4128 to collect specimens. The authors are grateful to $G$. Ingle de la Mora from INAPESCA for allowing us to use of the Image Capture System and to L.G. Núñez García for support in maintaining fish stocks at PExPA.

\section{REFERENCES}

Alvarez, J. \& L. Navarro. 1957. Los peces del valle de México. Secretaría de Marina, Instituto Nacional de Pesca, Dirección de Pesca e Industrias Conexas, México, D.F. 62 p.

Amaro, R., M. Abuin \& L. Sánchez. 1996. Chromosomal evolution in salmonids: a comparison of Atlantic salmon, brown trout, and rainbow trout R-band chromosomes. Genetica 98: 297-302.

Appels, R., R. Morris, B. S. Gill \& C. E. May. 1998. Chromosome Biology. Springer Science and Bussiness Media New York. 401 p.

ARAl, K. 2001. Genetic improvement of aquaculture finfish species by chromosome manipulation techniques in Japan. Aquaculture 197: 205-228.

Arias-Rodriguez, L., S. Páramo-Delgadillo \& A. Durán-González. 2006. Caracterización citogenética del pez tropical de agua dulce Parachromis managuensis (Pisces: Cichlidae). Revista Biología Tropical 54 (1): $35-42$.

Arias-Rodriguez, L., L. Ibarra-Castro \& S. Páramo-Delgadillo. 2008. Los cromosomas mitóticos y meióticos del pez tropical Petenia splendida (Cichlidae). Revista Biología Tropical 56 (2): 895-907.

Barbour, C. D. 1973a. A biogeographical history of Chirostoma (Pisces: Atherinidae): a species flock from the Mexican plateau. Copeia 3: 533-556.

Barbour, C. D. 1973b. The systematics and evolution of the genus Chirostoma Swainson (Pisces: Atherinidae). Tulane Studies in Zoology and Botany 19 (3): 97-141.

BARRIGA-SoSA, I. D. L. A. 2001. Variabilidad morfométrica, merística y molecular de especies del género Chirostoma (Pisces: Atherinpsidae). Tesis de Doctorado en Ciencias Biológicas, Universidad Autónoma Metropolitana Iztapalapa, México. 199 p.

Barriga-Sosa, I. D. L. A., A. L. Ibañez-Aguirre \& J. L. Arredondo-Figueroa. 2002. Morphological and genetic variation in seven species of the 
endangered Chirostoma "humboldtianum species group" (Atheriniformes: Atherinopsidae). Revista de Biología Tropical 50 (1): 199-216.

Bariiga-Sosa, I. D. L. A., L. E. Eguiarte \& J. L. Arredondo-Figueroa. 2004. LoW but significant population subdivision of Chirostoma grandocule from Lake Patzcuaro, Michoacan, Mexico. Biotropica 36 (1): 85-98.

Barriga-Sosa, I. D. L. A., M. Y. Pérez-Ramírez, F. Soto-Aguirre, M. CastilloRivera \& J. L. ArRedondo-FigueroA. 2005. Inter-specific variation of the mitochondrial r16S gene among silversides, "Peces Blancos", (Atherinopsidae: Menidiinae) and its utilization for species identification. Aquaculture 250: 637-651.

Berlanga-Robles, C. A., J. Madrid-Vera \& A. Ruiz-Luna. 2002. Fish abundance and trophic structure from the commercial catch in Lake Patzcuaro, Mexico. Hidrobiologica 467: 117-122.

ClaRke, K. R. 1993. Non-parametric multivariate analysis of changes in community structure. Australian Journal of Ecology 18: 117-143.

Da Silva Cortinhas, M. C., M. M. Cestari, A. C. Swarca \& A. S. Fenocchio. 2003. First chromosome data about the silverside Atherinella brasiliensis (Atheriniformes: Pisces) from the south coast of Brazil. Conventional, C-NOR and $\mathrm{CMA}_{3}$ bandings and FISH studies. Caryologia 56: 187-191.

Denton, T. E. 1973. Fish chromosome methodology. Charles C. Thomas, Chicago, Illinois, EEUU. 166 p.

Feldberg, E. \& L. A. C. Bertollo. 1985. Karyotypes of ten species of neotropical cichlids (Pisces: Perciformes). Caryologia 38: 257-268.

GajaRdo, G. M. 1992. Karyotypes of Basilichthys michrolepidotus and Basilichthys australis (Pisces: Atherinidae). Copeia 1: 256-258.

Galetti, P. M. JR., C. T. Agullar \& W. F. Molina. 2000. An overview on marine fish cytogenetics. Hydrobiologia 420: 55-62.

García-Martínez, R. M., 0. Mejía, F. J. García De León \& I. D. L. A. BarrigaSoSA. 2015. Extreme genetics divergence in the endemic fish Chirostoma humboldtianum (Valenciennes, 1835): implications for its conservation. Hidrobiológica 25 (1): 13-18.

Gyldenholm, A. 0., \& J. J. Scheel. 1971. Chromosome numbers of fishes. Journal of Fish Biology 3: 479-486.

Hammer, Ø., D. A. T. Harper \& P. D. Ryan. 2001. PAST: Paleontological Statistics Software Package for Education and Data Analysis. Paleotologia Electronica 4 (1): 9 pp.

Hodañová, L., L. Kalous \& Z. Musilová. 2014. Comparative cytogenetics of neotropical cichlid fishes (Nannacara, Ivanacara and Cleithracara) indicates evolutionary reduction of diploid chromosome numbers. Comparative Cytogenetics 8 (3): 169-183. doi: 10.3897/CompCytogen.v8i3.7279

HuXLEY, J. 1974. Evolution. The Modern synthesis. George Allen \& Unwin LTD, London. 617 p.

IUCN. 2015. International Union for the Conservation of Nature. The IUCN Red List of Threatened Species. Version 2015.1. http://www.iucnredlist.org (downloaded June 01, 2015).
JACKSON, R. C. 1971. The karyotype in systematics. Annual Reviews of Ecology and Systematics 2: 327-268.

Jeffrey, W. K. \& J. M. Fitzsimons. 1987. Karyology of three species of Eastern North American Atherinid fishes. Copeia 2: 505-509.

JiMÉNEZ, B. M. L. \& G. A. GRACIA. 1995. Evaluación de la pesquería multiespecífica de charales (Chirostoma spp., Pisces: Atherinidae) del lago de Pátzcuaro, Michoacán, México. Anales del Instituto de Biología UNAM, serie Zoología 66 (2): 205-231.

KInG, M. 1993. Species Evolution: The role of chromosome change. Cambridge University Press. 336 p.

Kovach, W. 1998. Multi-Variate Statistical Package. MVSP. Version 3.0.

Leggatt, R. A. \& G. K. Iwama. 2003. Ocurrence of polyploidy in the fishes. Reviews in Fish Biology and Fisheries 13: 237-246.

Levan, A., K. Fredga \& A. A. Sandberg. 1964. Nomenclature for centromeric position on chromosomes. Hereditas 52: 201-220.

Lyons J., G. González-Hernández, E. Soto-Galera \& M. Guzmán-Arroyo. 1998. Decline of freshwater fishes and fisheries in selected drainages of west-central Mexico. Fisheries Managements 23 (4): 10-18.

Machordom, A. \& I. Doadrio. 2001. Evolutionary history and speciation modes in the cyprinid genus Barbus. Proceedings of the Royal Society of London B 268: 1297-1306.

Mank, J. E. \& J. C. Avise. 2006. Phylogenetic conservation of chromosome numbers in Actinopterygiian fishes. Genetica 127: 321-327.

Martins, I. C., A. L. Portella-Castro \& H. F. Julio. 1995. Chromosome analysis of five species of the Cichlidae family (Pisces: Perciformes) from Parana River. Cytologia 60: 223-231.

MatThey, R. 1973. The chromosome formulae of eutherian mammals. In: Chiareli, A. B. \& E. Capanna (Eds.). Cytotaxonomy and vertebrate evolution, Academic Press, New York, pp. 531-616.

Merlo, M. A., I. Cross, C. Sarasquete, J. L. Palazón-Fernández \& L. Rebordinos. 2005. Caracterización cromosómica del pez sapo Halobatrachus didactylus (Schneider, 1801) (Teleostei: Batrachoididae) mediante hibridación in situ de fluorescencia. Boletín Instituto Español de Oceanografía 21 (1-4): 239-246.

Mercado-Silva, N., J. Lyons, E. Díaz-Pardo, A. Gutiérrez-Hernández, C. P. Ornelas-García, C. Pedraza-Lara \& M. J. Vander Zander. 2006. Longterm changes in the fish assemblage of the Laja River, Guanajuato, central Mexico. Aquatic Conservation: Marine and Freshwater Ecosystems 16: 533-546.

Muñoz, C., M. Nirchio, J. E. Pérez, E. Ron, C. Oliveira \& I. A. Ferreira. 2006. Cytogenetic characterization of the silverside fish Odontesthes regia (Humboldt, 1833) (Teleostei: Atheriniformes: Atherinopsidae) from Iquique, Chile. Revista de Biología Marina y Oceanografía 41 (1): 57-62.

NayyaR, R. P. 1966. Karyotype studies in thirteen species of fishes. Genetica 37: 78-92.

Nelson, J. S. 1994. Fishes of the world. 3rd ed. New York, John Wiley, Sons, Inc. 600 p. 
OCALEWICz, K. \& S. DoBosz. 2009. Karyotype variation in the albino rainbow trout (Oncorhynchus mykiss (Walbaum)). Genome 52: 347-352.

NOM-059-Semarnat-2010. Norma Oficial Mexicana. Diario Oficial de la Federación, México. Diciembre. 77 pp.

RAB, P., P. LIEHMAN \& M. Prokes. 1983. Karyotype of Cichlasoma tetracanthum (Pisces: Cichlidae) from Cuba. Folia Zoologica 32: 185-188.

Rosas, C. P. M. \& Y. L. F. SAsso. 2005. El pescado blanco. Revista Digital Universitaria 6 (8): 2-18.

SALAS, E. \& J. BozA. 1991. Citotaxonomía comparativa de tres especies de Cichlasoma (Pisces: Cichlidae) nativas de Costa Rica. Revista de Biología Tropical 39: 219-224.

Schreier, A. D., B. May \& D. A. Gille. 2013. Incidence of spontaneous autopolyploidy in cultured populations of white sturgeon, Acipenser transmontanus. Aquaculture (416-417): 141-145.

Schultz, R. J. 1980. Role of polyploidy in the evolution of fishes. In: Lewis, W. H. (Ed.). Polyploidy: Biological Relevance. Plenum Press, New York, pp. 313-340.

Sczepanski, T. S., R. B. Noleto, D. L. Z. Kantek, M. C. S. Cortinhas \& M. M. Cestari. 2007. Classical and molecular cytogenetics of Atherinella brasiliensis (Teleostei: Atheriniformes) from South coast of Brazil. Journal of Fish Biology 71: 453-460.

Soвti, R. C., G. Oвe \& R. C. Athwal. 2002. Some aspects of chromosome structure and function. Kluwer Academic Publishers. New Delhi, India. $237 \mathrm{p}$.

Sola, L., G. L. Natil \& S. Cataudella. 1988. Cytogenetical characterization of Odontesthes bonariensis (Pisces: Atherinidae), an Argentine species introduced in Italy. Genetica 77 (3): 217-224.

Soria-Barreto, M., J. Paulo-Maya, A. Chacón-Torres \& G. Segura. 1998. Peces dulceacuícolas mexicanos. Chirostorna estor (Pisces: Atherinidae). Zoología Informa 38: 33-46.

Soto-Galera, E., E. Díaz-Pardo, E. López-López \& J. Lyons. 1998. Fish as indicators of environmental quality in the Río Lerma Basin, México. Aquatic Ecosystem Health and Management 1: 267-276.

Stat Soft Inc. 2011. STATISTICA Version 10.

Steven, L. C. \& C. Smith. 2004. Polyploidy in fishes: patterns and processes. Biological Journal of the Linnean Society 82: 431-442.

Strüssmann, C. A., B. C. Ng, T. Oshiro \& F. Takashima. 1993. Triploidy induction in an Atherinid fish, the pejerrey (Odontesthes bonarensis). The Progressive Fish-Culturist 55 (2): 83-89.

Strüssmann, C. A., T. Akaba, K. IJima, K. Yamaguchi, G. Yoshizaki \& F. TakashlMA. 1997. Spontaneous hybridization in the laboratory and genetic markers for the identification of hybrids between two atherinid species, Odontesthes bonarensis (Valencinnes, 1835) and Patagonia hatcheri (Eigenmann, 1909). Aquaculture Research 28: 291-300.

Thompson, K. W. 1979. Cytotaxonomy of 41 species of neotropical Cichlidae. Copeia 4: 679-691.
Thitiot-Quiévreux, C. 1994. Chromosomal genetics. In: Beaumont, A. R. (Ed.). Genetics and Evolution of Aquatic Organisms. Chapman \& Hall, London, pp. 369-423.

Thorgaard, G. H. 1983. Chromosomal differences among rainbow trout populations. Copeia 1983: 650-662.

Tripathy, N. K. \& C. C. Das. 1988. Karyotypes of five Indian Perciform fishes. Copeia 1: 231-233.

Uribe-AlCoCer, M. 1988. The karyotype of three ariid catfishes from México. Genome 30 (Suppl. 1): 256.

Uribe-Alcocer, M., B. L. Náder-García \& N. Valdés-Morales. 1992. The Chromosomes of two Cichlid fishes from México, Cichlasoma ellioti and Cichlasoma trimaculatum. Japan Journal Ichthyology 39 (2): 174-177.

Uribe-Alcocer, M., M. C. Téllez-Vargas \& P. Díaz-Jaimes. 1999. Chromosomes of Cichlasoma istlanum (Perciformes: Cichlidae) and karyotype comparison of two presumed subspecies. Revista de Biología Tropical 47: 1051-1059.

Uribe-Alcocer, M., H. Olvera-García \& P. Díaz-Jaimes. 2002. Karyotype analysis in three species of the genus Chirostoma (Atheriniformes, Atherinidae). Ichthyological Research 49: 85-88.

Uribe-Alcocer, M. \& P. Díaz-Jaimes. 2003. Análisis cariotípico de un pescado blanco y de dos charales del género Chirostoma (Pisces: Atherinopsidae): evolución cariotípica en el Orden Atheriniformes. In: Rojas-Carrillo, P. M. \& D. Fuentes-Castellanos (Eds.). Historia y avances del cultivo de pescado blanco. Instituto Nacional de Pesca. México, pp. 79-105.

Uyeno, T. \& R. R. Miller. 1973. Chromosomes and the evolution of the Plagopterin fishes (Cyprinidae) of the Colorado River System. Copeia 4: 776-787.

VASIL'Ev, V. P. 2009. Mechanisms of polyploid evolution in fish: Polyploidy in Sturgeons. In: Carmona, R., A. Domezain, M. García-Gallego, J. A. Hernando, F. Rodríguez \& M. Ruiz-Rejón. (Eds.). Biology, Conservation and Sustainable Development of Sturgeons. Springer Science + Business Media B.V., pp. 97-117.

Warkentine, B. E., C. L. Smith \& J. W. Rachlin. 1987. A revaluation of the karyotype of the Atlantic silverside Menidia menidia. Copeia 1: 222-224.

White, M. J. 1973. Animal Cytology and Evolution. $3^{\text {rd }}$ edition University Press, Cambridge, UK, $961 \mathrm{p}$.

WHITE, M. J. 1978. Chain processes in chromosomal speciation. Systematic Zoology 27 (3): 285-298.

White, M. J. 1978a. Modes of speciation. Freeman. San Francisco, CA, USA. $455 \mathrm{p}$.

Recibido: 20 de noviembre de 2015.

Aceptado: 05 de febrero de 2016. 